\title{
Inquiry-Based Active Learning: The Enhancement of Attitude and Understanding of the Concept of Experimental Design in Biostatics Course
}

\author{
Suwondo $^{1} \&$ Sri Wulandari ${ }^{1}$ \\ ${ }^{1}$ The Faculty of Education University of Riau, Indonesia \\ Correspondence: Suwondo, The Faculty of Education, University of Riau, Indonesia. E-mail: \\ wondo_su@yahoo.co.id
}

Received: August 1, 2013 Accepted: August 16, 2013 Online Published: August 30, 2013

doi:10.5539/ass.v9n12p212 URL: http://dx.doi.org/10.5539/ass.v9n12p212

\begin{abstract}
The purpose of this study is to identify the effect of using active inquiry-based learning in conducting experiment in the subject of Biostatic. The experiment included 1) Instructional Re-designation, 2) planning of the active learning process, and 3) application of the inquiry-based active learning. The sample involved 96 trainee teacher enrolled in biology program in the university of Riau, Indonesia, as respondents, and they were divided into two groups 48 respondents for year 2011 and 48 respondents for year 2012. To collect data, questionnaire, focusing on attitude from peers' perspectives, whereas the test was given to identify students' level of understanding the content of biology were employed. As the students were given test after finishing each chapter they learnt. The finding shows that attitude of the students changed after using the inquiry-based learning. In addition, the finding shows that as a result of using inquiry-based learning, achievement of the majority of the students from two groups in 2011 and 2012 was at good level. This means that the inquiry-based learning can be used as one of the method to increase students' achievement and change their style of learning especially in conducting experiment in science subject.
\end{abstract}

Keywords: active inquiry-based learning, achievement, attitude, science, trainee teachers, biostatics

\section{Introduction}

The Biostatics subject taken by the secondary school Biology teacher trainees of the Biology Education Program involves the learning of the application of statistical methods in analysing biological problems is regarded as the fundamental biological knowledge or its applied fields. The aim of the subject is to make students understand the concept of experiment using the Complete Randomized Design and Randomized Block Design. This subject highly supports the students' completion of their final project (essay) and other subjects which employ experimental approaches.

The Biostatics course which uses active learning strategy must be restructured in terms of its learning design by emphasizing on the elements of active learning. In this regard, the development and implementation of the learning design which is focused on active learning and centred upon the students are required. The restructuration of the instructional design is made after analyzing the traditional courses which is seen to have some flaws.

The implementation of problem-based learning makes the integration of problems in the activities of Biostatics course easier. The inquiry-based active learning approach is executed by 1) Redesigning the instructional implementation which is able to give contributions to the inquiry-based active learning, and 2) innovating the learning based on the experimental design to enable other educators to learn from the findings of the research conducted.

Active learning, according to Allen and Tanner (2005), involves the activities of searching for new information, organizing the information in a meaningful manner, and gaining the chance to explain it to others. The teaching emphasizes the interaction among peers and involves activities and feedback, where students are given consistent opportunities to participate in the learning process in the classroom, and develop their critical thinking.

Inquiry is a learning approach that is potent in instilling the fundamentals of scientific thinking into the self of 
the students, encouraging the students to learn more on their own and develop their creativity in analyzing problems. Furthermore, inquiry is also an approach that is able to develop the values and attitudes that are highly required to enable the students to think scientifically (Sagala 2004 \& Latif, 2011). The inquiry approach which obliges students' active involvement has been proved to be able to improve learning performance and scientific attitudes towards science and mathematics (Haury, 1993). The investigation done by the students is the backbone of the inquiry approach. This investigation focused on the effort of understanding the scientific or mathematical concepts since these elements will enhance the skills of students' thinking process. It is believed that the comprehension of concepts is the result of the scientific thinking processes (Blosser, 1990). The inquiry approach possesses five general components; which consist of Question, Student Engangement, Cooperative Interaction, Performance Evaluation, and Variety of resource (Garton, 2005).

Trowbridge in Saliman (2010) defined inquiry as the process of defining and investigating problems, formulating hypothesis, planning experiment, collecting data, and describing the conclusions of the problems. Furthermore, inquiry-based teaching simply means creating a learning environment which centres upon the students by providing sufficient guidance in reaching a discovery.

The teaching of biological science will be more effective with the employment of a learning model which involves real world application through the integration of the inquiry-based learning steps (Gee \& Wong, 2006). Inquiry model is able to increase students' ability to think critically (Kitot, Ahmad \& Seman, 2010). This study sought to find out about students' scientific attitude and comprehension after participating in the inquiry-based active learning concerning the concept of experimental design in the Biostatics course.

\section{Statement of the Problem}

The Biostatics course which is Teacher-Centred-Learning (TCL) oriented, might be effective to a large number of students, yet due to its one-way interaction learning always seems passive and weak in stimulating students' motivation, confidence, and enthusiasm. Weimer in Armbruster (2009) suggested that the traditional learning model causes the students to face difficulties in developing the essential skills of improving professional competence.

Past studies demonstrate that the difficulty that is always complained about by the students who study the Biostatics course revolved around the characteristics of the learning materials, loaded with the complicated concepts of experimental planning and data analysis method. This has caused students' understanding to tend to be partial and incomprehensive; a condition which leads to the low achievement of many students consequently (Suwondo, 2008; Wulandari, 2009). This situation is certainly associated with the teaching strategies that have been employed for a long time. In accordance with the policy of the Implementation of Competence-Based Curriculum at Riau University, instruction in the classroom should shift from being merely teacher-centred to student-centred instead. The changes in instructional approach and teaching strategies should be planned variously to enable students to think critically and creatively, as well as attain social sensitivity so that they can manage to overcome the problems in life.

The most visible issue witnessed is the students' poor scientific attitudes and dissatisfaction with the course which sometimes is quite dull and boring. Apart from that, students tend to only focus on the examinations compared to the attainment of complete comprehension of the course materials. Armbruster et al. (2009) proposed that the inquiry-based active learning which prioritizes the students in its instructional design is capable of enhancing students' scientific attitudes and elevating their performance, which leads to the increment in students' achievement.

\section{Purpose of the Study}

The purpose of this study is to identify the effect of using active inquiry-based learning in conducting experiment in the subject of Biostatic on students' attitude and achievement from two groups in 2011 and 2012. The achievement evaluation was conducted using tests on the biostatic syllabus content, whereas the attitude towards the involvement of active inquiry-based learning during carrying out experiment in the subject.

\section{Methodology}

The study sample involved 96 teacher trainees enrolled in biology program in the university of Riau, Indonesia who were chosen randomly, as respondents, and were divided into two groups, as 48 respondents were for year 2011 and 48 respondents for year 2012. The study used the 40 item questionnaire, focusing on the concepts of honesty, tolerance; discipline, hard work, creativity, autonomy, democracy and curiosity from peers' perspectives, in which the scale likert had four categories including 1) poor, 2) enough, 3)good, 4) very good. The pilot test of questionnaire shows that the value of Cronbach Alpha analysis is high, that is, between 0.80 and 0.85 . 
Another instrument was test which was categorized based on the university marking scale which are very good (81-100); good (70-80); satisfactory (60-69); poor (50-59), and failed $(<50)$. Three types of test were employed. Pre-test, test one and test two, as the students were given test one and test two after finishing some chapters they learnt. This was used to evaluate students' understanding of the content of the subject. In addition, the tests were prepared by an experienced senior lecturer in the subject.

To analyze the data obtained, descriptive analysis was used to find the percentage of students' attitudes towards and achievement in active inquiry-based learning in learning and conduction experiment for biology subject.

\subsection{Instructional Redesignation}

The existing Teacher-Centred-Learning-based instructional design of the Biostatics course was redesigned by infusing the concept of active learning which focuses on the students. The re-designation encompassed: the syllabus, lecture units, students' worksheets, and assessment tools. The concept of experimental planning was not changed. The product of the instructional re-designation were used in the learning development research and implemented in two academic years which were 2011 2012. The number of students who took the Biostatics subject under the Biology Education Study Program was 48 persons each. The observer has been teaching this subject for seven years, starting from 2005 until now. It was hoped that this study will lead to the enhancement of students' scientific attitudes and achievement in Biostatics as the result of the instructional design implemented.

\subsection{Planning the Active Learning Process}

The concept of the Complete Randomized Design and Randomized Block Design was not substantially modified to be learnt by the students, but changes in the aspect of its learning process took place to deeply understand the concept. The learning which was student-focused and inquiry-based, was implemented by allowing students to present the problems, investigating and discovering the concept, performing the tasks on their own, attending the classroom or field experiment. The re-designation of the lecture units was done by emphasizing on the active learning which was accompanied by the problem-based Student Leadership Training. During the lectures, students were motivated and encouraged through the reading of literature sources and discussion on issues.

The previous final evaluation only stressed on the cognitive aspects, which are the Mid Semester Exam and End Semester Exam. These forms of evaluation were redesigned into performance-based evaluation. The assessment consisted of three domains which are: (1) Cognitive, (2) Affective, and (3) Psychomotor. The cognitive domain was evaluated based on the Mid Semester Exam and End Semester Exam; the affective domain was assessed based on students' activity throughout the learning process which included; 1 . Responsibility 2. Involvement in the group tasks, 3. Students' activeness in class discussion; the psychomotor domain was appraised based on the individual tasks and group works, activity report, and work performance.

\subsection{The Application of the Inquiry-Based Active Learning}

Active learning means that every lecture was occupied with problem-based learning. Students were organized into cooperative groups starting from the third lecture until the last lecture (one semester). In the academic years 2011 and 2012, the number of cooperative groups was the same, which was 8 groups altogether. During each lecture, one problem was presented to be investigated by every group until one conclusion was made. Throughout the session, the lecturer would monitor the progress and provide guidance from one group to another group if there emerged any difficulties. Students' activities were clearly visible throughout the group and class discussions. To ensure the comprehension of the concept of the materials, each of the groups was asked to report the discussion results to the class.

The problems presented were always related to the biology discipline, such as: "the Effect of urea fertilizer on the growth of soybean plants". To analyse the problems, students needed to execute investigation by doing field experiment until they managed to discover and understand the concept of the Complete Randomized Design and Randomized Block Design. This activity required the students to understand how to make the blueprints for the experimental planning; and infusing the experimental unit into the blueprints by performing randomization, executing the experiment, collecting data, analyzing data, and deriving conclusions.

\section{Findings and Discussions}

The conventional Biostatics course that has been implemented which often emphasized more on the content rather than the process has caused the students to be passive and having the tendency to decrease in achievement. The instructional re-designation that was done by stressing on the active learning which focused on the students clearly producing good results; which is the improvement of students' scientific attitude and achievement. 


\subsection{Students' Scientific Attitude}

The findings of this research show that the inquiry-based active learning was able to establish better scientific attitudes in the students. This was seen in the two academic years observed which are 2011 and 2012. Each of the scientific attitudes evaluated experienced some enhancement although there was not much difference in the scores and still maintained in the same category. The results of the evaluation of students' scientific attitudes through the implementation of the inquiry-based active learning were presented in Figure 1.

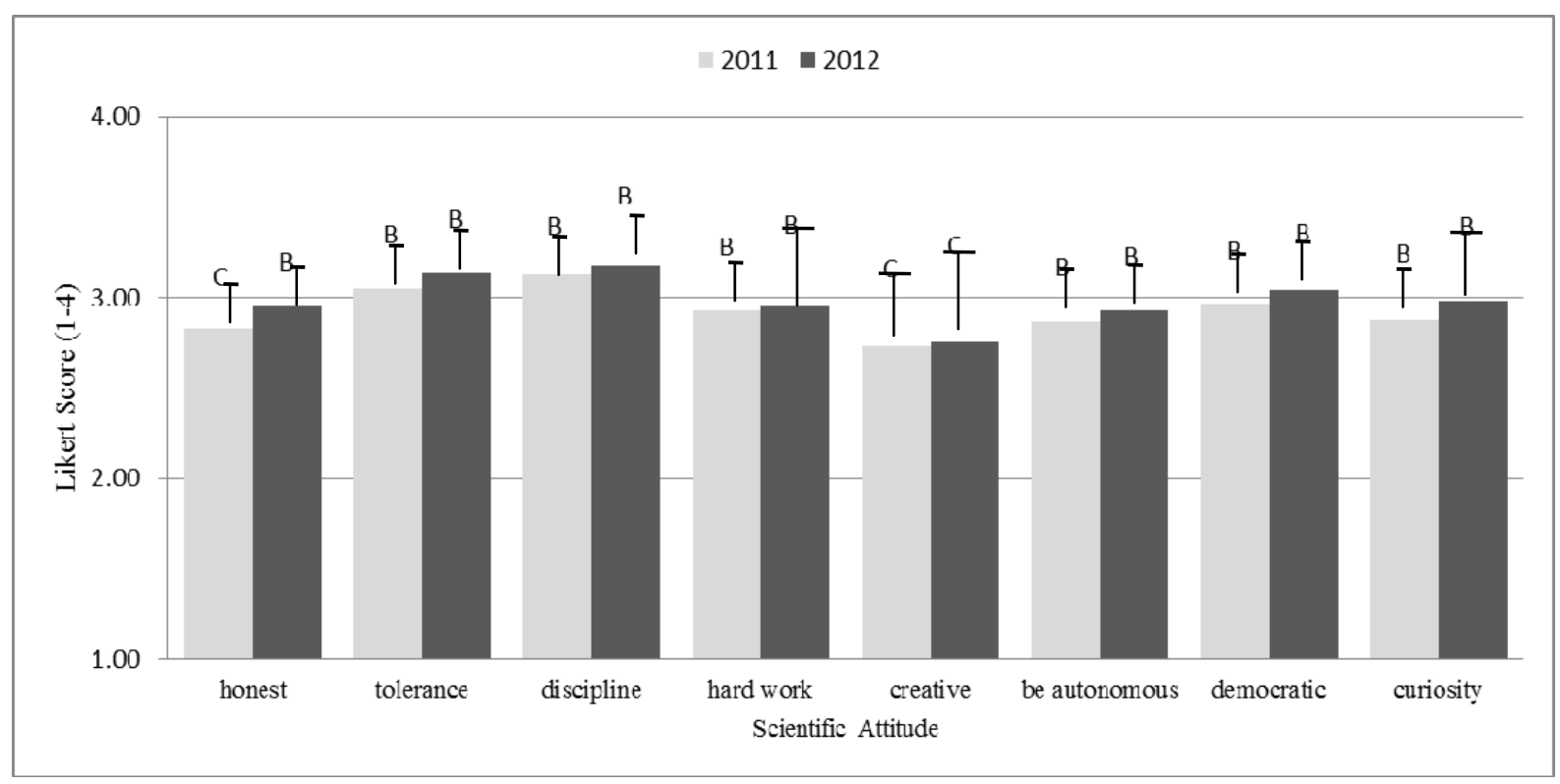

Fugure 1. Students' scientific attitudes through the inquiry-based active learning in the biostatics subject in years 2011 and 2012

The data show that the level of most of the constructs of the students' attitudes after using the active inquiry learning were at quite good level in the years 2011 and 2012.The scientific attitudes focused on in this study are honest, tolerant, disciplined, hard-working, creative, independent, democratic, and curious. These attitudes were not seen in the lectures which employed the conventional approach. This is parallel with the findings of the research done by Ni Putu Erni (2011) and Sirait (2012) which found that the conventional learning model was not yet able to develop the formal thinking and scientific attitudes to the better, since in the conventional classroom the students tended to remain silent while listening to the instructor's lecture compared to the lectures which implemented the inquiry-based learning model.

The scientific attitude of discipline showed a higher score compared to other scientific attitude. Throughout the lectures students' attendance was $100 \%$. The rules that had been agreed to in the course contract were starting to be internalized. Simsek and Kabapinar (2012) proposed that scientific attitudes are highly required to motivate the students in the learning activities. Discipline is a very important scientific attitude in the effort of increasing the achievement level. Sheaa and Bidjeranoc (2012) claimed that the attendance to lectures is closely-related to students' desire to gain knowledge. This indicates that students' disciplines were starting to generate and would eventually determine their learning performance.

The crucial element of the instructional re-designation in this course was that the investigation done through group works and the reporting of the results to the class were very meaningful to students, since most of them were actively involved and serious in the activity of analyzing the problems. The research done by Suwondo and Wulandari (2011) discovered that the involvement of group works in analyzing problems generated the spirit of hard works and creativity in students. Simseka and Kabapinarb (2012) suggested that research-based learning will give positive impacts on students' conceptual understanding and knowledge process skills.

During every group task, the lecturer monitored the progress of the groups by joining the discussion of each group. Throughout the observation, the lecturer rarely found a group that was not seriously involved in the activity. This indicates the positive impacts received by the students which had caused their scientific attitudes that were evaluated throughout the study to be in the "good" category. The score of the scientific attitude of 
tolerance in the academic year of 2011 was 3,05 which was above 3; whereas in 2012 the score was 3,13, which was also above 3. Wahyudin, et al. and Wijayanti in Ni Putu Erni (2012) stated that in the inquiry-based learning, the teacher or lecturer are supposed to guide the students especially the ones who never have the experience of learning through the inquiry-based activities in order to assist them overcome the difficulties in understanding a concept. Throughout the discussion that took place, students' tolerance and democratic qualities were exhibited in their act of appreciating the opinions from peers, helping colleagues during the completion of the group tasks, and providing suggestions when a member of their groups were less accurate in solving the problems presented. Dewi et al (2013) suggested that the inquiry-based learning gives students the opportunity to be actively involved in the process of learning how to analyse problems fairly, objectively, critically, openly, and cooperatively. This will definitely give positive influences on the students' scientific attitudes.

The scores of the scientific attitudes of honesty, hard works, independence, and curiosity were still below three. These scientific attitudes were associated with the learning materials in the Biostatics course which required logical, critical, and analytical thinking in solving problems. Students were seen to still be hesitant and unconfident in selecting an analysis to be used to solve a case, causing to keep referring to books and asking friends even during the examinations. The number of students who managed to solve problem individually were minimal, yet at least $50 \%$ or more of the groups were able to solve the problems given. According to Gehring and Eastman (2008) and Ellen et al, (2012), the inquiry-based active learning possesses a wide opportunity for students to develop their scientific attitude to the better. The inquiry method is able to cultivate the fundamentals of scientific thinking in students, enabling them to learn on their own even during the lecture. This will generate their creativity in solving problems.

\subsection{Students' Achievement}

Students' achievement which was evaluated based on the pre-test and test of each of the discussion subject indicated that there was an increase in their accomplishment in the academic years of 2011 and 2012, as seen in table 1.

Table 1. Students' achievement through the inquiry-based active learning in the biostatics program in years 2011 and 2012

\begin{tabular}{ccccccc}
\hline \multirow{2}{*}{ Year } & \multirow{2}{*}{ Number of Students } & \multicolumn{3}{c}{ values } & Average & Category \\
& & Pre-test & Test 1 & Test 2 & & \\
\hline 2011 & 48 & 61.44 & 71.83 & 73.57 & 72.7 & Good \\
2012 & 48 & 70.06 & 72.92 & 74.9 & 73.91 & Good \\
\hline
\end{tabular}

The improvement of students' achievement was associated with the change in the instructional design implemented in the lectures. Active learning had brought changes in students' way of thinking. Given the problems to be analysed during each lecture, students' were encouraged to be hard-working, creative, and curious; leading to the enhancement in their achievement. Walker et al, in Armbrusteret al. (2009) claimed that the active learning that focuses on the students is able to increase academic performance. The average value of the students' achievement the academic year 2011 was 72.7 (good); whereas the score in the academic year 2012 was 73.91 (good). The value of students' achievement in the academic years of 2011 and 2012 were not significantly different $(t=0.12 ; t>0.05)$. This denotes that the application of the inquiry-based active learning was able to consistently increase the achievement of students in the Biostatics course. If compared to the lectures with conventional approach, this achievement showed a significant difference $(\mathrm{t}=2.44 ; \mathrm{t}<0.05)$. Therefore, it can be concluded that the inquiry-based active learning was able to improve students' achievement in the Biostatics course.

The value of students' achievement as seen in Figure 2 showed that students' accomplishment was at the "satisfactory" level to the "very good" level be it in the academic year 2011 or 2012. 


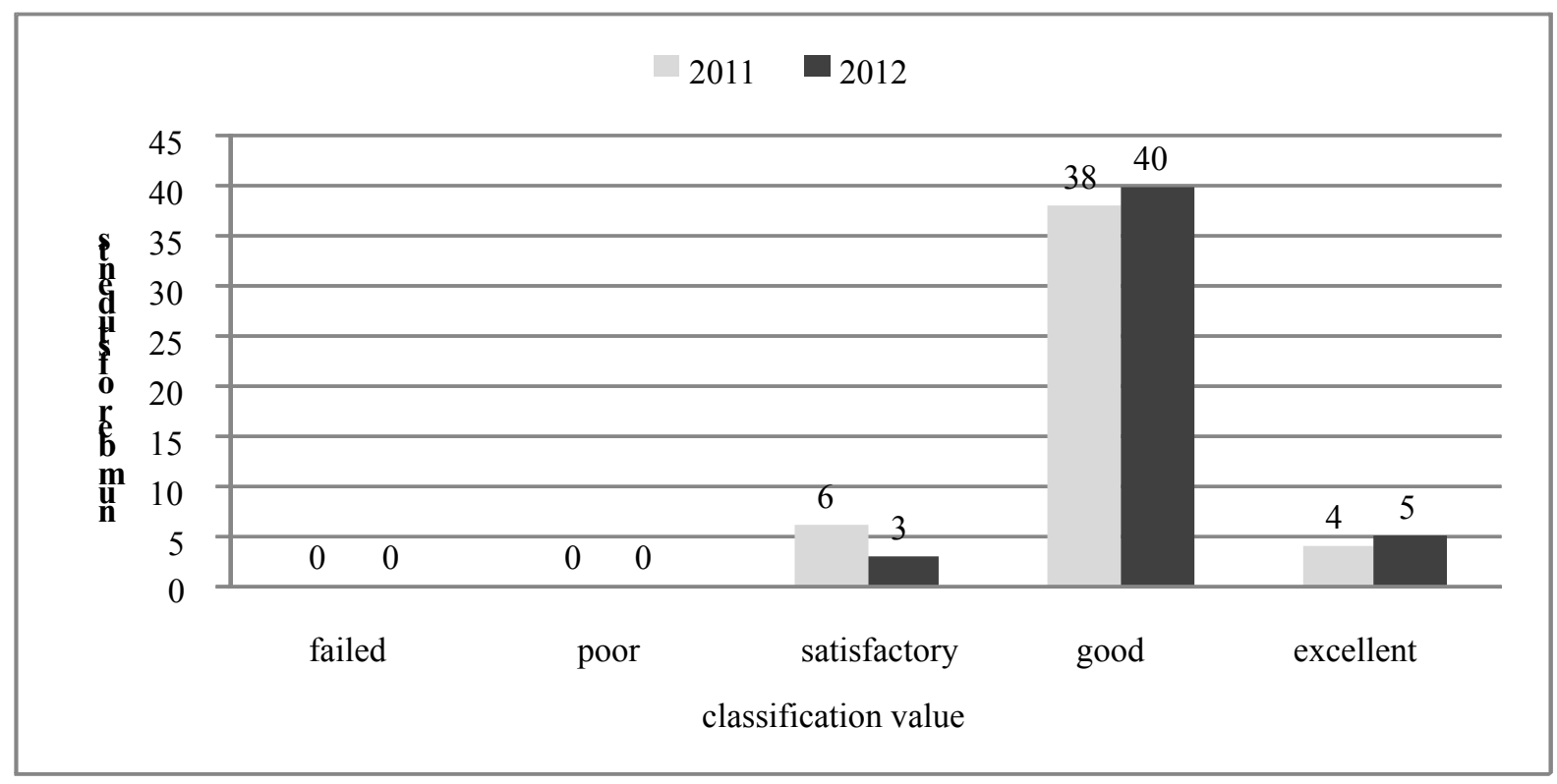

Figure 2. The categories of students' achievement through the inquiry-based active learning in the biostatics subject, in years 2011 and 2012

The number of students who were in the "very good" category was still low, with the total number of 4 students $(8.33 \%)$ in the academic year 2011, and 5 students $(10.41 \%)$ in the academic year 2012. The category which had the highest number of students was the "good" category, with the total number of 38 students $(79.16 \%)$ in the academic year 2011, and 40 students (83.33\%) in the academic year 2012. The most important matter in this instructional re-designation is that there were no students who fell under the "poor" and "failed" categories. Furthermore, the decline in values under the "satisfactory" category shows that there was an increase in students' academic achievement.

\section{Implication and Recommendation}

The implication of the study is that active inquiry based learning promotes students' achievement in academic subjects especially at university level. Furthermore, active inquiry-based learning can also change the students' learning style, that is, they can be more independent, creative, tolerant, disciplined and so on. This can also change the style of teaching at university, i.e., shifting from teacher-centred to learner-centred. In learning subject content in classroom as well as conducting experiment in the lab, students' attitudes towards active inquiry-based learning changed, that is, they are keen to use it in future.

The study recommends that the teachers should apply active inquiry-based learning in the classroom to transit from teacher-centred style of teaching to student-centred learning. Furthermore, it is suggested that universities provide more facilities to enable the teachers of the other subjects to employ active inquiry-based learning in the classroom and lab. The university syllabus also should be based on active inquiry-based learning. Additionally, this active learning approach can be one of the innovations of the biological science studies in higher education.

\section{Conclusion}

The instructional redesignation which is executed by implementing active learning is highly required in the biological science learning process. The development and implementation of instructional design of the inquiry-based active learning give a significant change in the lecture environment to put its main on the students, so that they can experience the improvement in their scientific attitudes and performance which will positively influence the students' achievement in the Biostatics course. The active inquiry-based learning should be employed for all subjects of university to open a new chapter in teaching and learning in higher education level.

\section{References}

Allen, D., \& Tanner, K. (2005).Infusing active learning into the large-enrollment biology class: seven strategies, from the simple to complex. Cell Biol. Educ., 4, 262-268. http://dx.doi.org/10.1187/cbe.05-08-0113

Armbruster, P, M, Johnson, E., \& Weiss, M. (2009). Active Learning and Student-centered Pedagogy Improve 
Student Attitudes and Performance in Introductory Biology. Journal of Life Sciences Education, 8, 203-213. http://dx.doi.org/10.1187/cbe.09-03-0025

Blosser, P. E., \& Helgenson, S. L. (1990). Selecting Procedures for Improving the Science Curriculum. Columbus, OH: ERIC Clearinghouse for Science, Mathematics, and Environment Education.

Casem, M. L. (2006). Student Perspectives on Curricular Change: Lessons from an Undergraduate Lower-Division Biology Core. Journal of Life Sciences Education, 5, 65-75. http://dx.doi.org/10.1187/cbe.05-06-0084

Derting, T. L., \& May, D. W. (2010). Learner-Centered Inquiry in Undergraduate Biology: Positive Relationships with Long-Term Student Achievement. Journal of Life Sciences Education, 9, 462-472. http://dx.doi.org/10.1187/cbe.10-02-0011

Dewi, N. L., Dantes, N., \& Sadia, W. (2013). Pengaruh Model Pembelajaran Inkuiri TerbimbingTerhadap Sikap Ilmiah Dan Pencapaian IPA. e-Journal Program Pascasarjana Universitas Pendidikan Ganesha. Jurusan Pendidikan Dasar., 3, 78-82.

Erni, N. P. (2011). Pengaruh Model Pembelajaran Guided InquiryTerhadap Kemampuan Berpikir Formal dan Sikap Ilmiah Siswa. Program Studi Pendidikan IPA STIKIP. Bali.

Garton, J. (2005). Inquiry-Based Learning. New York: Technology Integration Academy.

Gee, K, A., \& Wong, K. (2012). A cross national examination of inquiry and its relationship to student performance in science: Evidence from the Program for International Student Assessment (PISA) 2006. International Journal of Educational Research, 53, 303-318. http://dx.doi.org/10.1016/j.ijer.2012.04.004

Gehring, K., \& Eastman, D. (2008). Information Fluency for Undergraduate Biology Majors: Applications of Inquiry-based Learning in a Developmental Biology Course. Journal of Life Sciences Education, 7, 54-63. http://dx.doi.org/10.1187/cbe.07-10-0091

Goldey, E. S., Abercrombie, C. L., Ivy, T. M., Kusher, D. I., Moeller, J. F., Rayner, D. A., ... Natalie, W. (2012). Biological Inquiry: A New Course and Assessment Plan in Response to the Call to Transform Undergraduate Biology. Journal of Life Sciences Education, 11, 353-363. $\mathrm{http}: / / \mathrm{dx}$.doi.org/10.1187/cbe.11-02-0017

Haury, L. D. (1993). Teaching Science through Inquiry. Columbus, OH: ERIC Clearinghouse for Science, Mathematics, and Environment Education.

Kitot, A., Ahmad, A., \& Seman, A. (2010). The Effectiveness of Inquiry Teaching in Enhancing Students' Critical Thinking. Procedia-Social and Behavioral Sciences, 7, 264-273. http://dx.doi.org/10.1016/j.sbspro.2010.10.037

Labov, R. A., \& Yamamoto, R. (2010). Integrated Biology and Undergraduate Science Education: A New Biology Education for the Twenty-First Century? Journal of Life Sciences Education, 9, 10-16. http://dx.doi.org/10.1187/cbe.09-12-0092

Latif, A. (2011). Strategi Pembelajaran Inkuiri Bermuatan Karakter. Retrieved from http://pahlawan.com/strategi-pembelajaran-ikuiri. Akses tanggal 20 Maret 2013.

Metz, A. M. (2008). Teaching Statistics in Biology: Using Inquiry-based Learning to Strengthen Understanding of Statistical Analysis in Biology Laboratory Courses. Journal of Life Sciences Education, 7, 317-326. http://dx.doi.org/10.1187/cbe.07-07-0046

Ratni, S. (2012). Pengaruh Model Pembelajaran Inquiry Training Terhadap Pencapaian Siswa VIII MTSN 3 Medan. Jurnal Pendidikan Fisika, 1, 21-26.

Sagala, S. (2004). Konsep dan Makna Pembelajaran.Bandung: Penerbit Alfabeta.

Sheaa, P., \& Bidjeranoc. (2012). Learning presence as a moderator in the community of inquiry model. Procedia - Social and Behavioral Sciences, 59, 316-326.

Simsek, P., \& Kabapinar. (2012). The effects of inquiry-based learning on elementary students' conceptual understanding of matter, scientific process skills and science attitudes. Procedia - Social and Behavioral Sciences, 2, 1190-1194.

Sukardi. (2003). Metodologi Kajian Pendidikan. Jakarta: Penerbit Bumi Aksara.

Suwondo dan Wulandari, S. (2011). Peningkatan Pencapaian Mahasiswa Melalui Integrasi Model Pembelajaran Kooperatif dengan Inquiry Pada Mata pelajaran Biostatistik Di Program Studi Pendidikan 
Biologi. Laporan Kajian. Lembaga Kajian Universitas Riau. Pekanbaru.

Suwondo. (2008). Penerapan Model Pembelajaran Problem Based Learning (PBL) untuk Meningkatkan Kemampuan Pemecahan Masalah Pada Konsep Rancangan Eksperimen Dalam Mata pelajaran Biometri. Jurnal Pendidikan, 1, 25-30.

Trowbridge, L. W., \& Bybee, R. W. (1990). Becoming a Secondary School Science Teachers. Melbourne: Merill Publishing Company.

Wood, B. (2003). Inquiry-Based Undergraduate Teaching in the Life Sciences at Large Research Universities: A Perspective on the Boyer Commission Report. Journal Cell Biology Education, 2, 112-116. http://dx.doi.org/10.1187/cbe.03-02-0004

Wulandari, S. (2009). Peningkatan Pemahaman Mahasiswa Dalam Penerapan Konsep Rancangan Eksperimen Melalui Pembelajaran Kooperatif Pada Mata pelajaran Biometri. Jurnal Biogenesis, 2, 20-25.

\section{Copyrights}

Copyright for this article is retained by the author(s), with first publication rights granted to the journal.

This is an open-access article distributed under the terms and conditions of the Creative Commons Attribution license (http://creativecommons.org/licenses/by/3.0/). 